\title{
Public Sphere Dialogue in Online Newspapers and Social Spaces: The Nuclear Debate in Post Fukushima France
}

\author{
ANN-LOUISE DE LA POYPE \\ University of Leicester, $U K$ \\ SURESH SOOD \\ University of Technology Sydney, Australia
}

\begin{abstract}
The meltdown at the Japanese Fukushima Daiichi nuclear power plant in March 2011 provided a trigger to contribute this research about the ways that French newspapers facilitate (or restrict) a public dialogue on the issue of nuclear energy. Nuclear power not only generates over $75 \%$ of the electricity in France but also sustains a healthy domestic job creation program and drives nuclear technology exports. Hence, the absence of public debate amongst the French in nuclear energy over the long term is not surprising. Against this backdrop of French nuclear interests and post Fukushima, this paper presents a French language computer-mediated discourse analysis on nuclear debates and discussions taking place online in the hybrid public sphere. This space straddles user-generated content in the public comment spaces of newspapers embracing the spectrum of political persuasions (Le Figaro, Le Monde and Liberation) and social media.
\end{abstract}

Qualitative and quantitative research methods uncover citizen interactions within the online public sphere comprising newspapers. Findings illuminate the progress of deliberations on nuclear power in online newspapers following a process of agenda setting through news stories, providing space for public dialogue and the digital curating of social media commentary. Furthermore, the research reveals the relevance of the Habermasian public sphere concept within the context of online newspapers. Key learning for the role of the media in fostering the democratic process using social media and insights for the political communications landscape within the context of the nuclear debate compliment the research.

\section{Nuclear power industry, economy and culture}

In the 21 st century, the French have opportunities to publicly communicate beyond chatting over a glass of wine and join the rest of the world in the Internet behaviour of interacting with online newspaper readers, following Twitter, viewing YouTube videos on mobile phones, or simply engaging in so-called "clicktivism" (White, 2010) by signaling approval of digital texts with a Facebook "like". If French citizens are indeed conversing about nuclear power online, this represents a significant break from a recent past where debate has been limited by cultural attitudes and shaped by the executive and administration. The Fukushima nuclear accident in March 2011 thrust the topic of nuclear energy into the headlines and the timing ensured the nuclear issue became a political debate in the lead-up to the 2012 presidential elections (Brouard et al, 2012). The relationship between the French and the nuclear industry is complex with a nuclear discourse deeply embedded in the French psyche. This affects news coverage and discussions at both a political and civic level. 
Nuclear power is a "national heritage" (Oursel, 2012) generating over 75\% (Beaupuy and Connan, 2012) of electricity in France and sustaining job estimates of 400,000 people (Sayare, 2012). On-going job growth is commensurate with overseas partnerships (Porritt, 2012). Building on this nuclear foundation, France has achieved an unassailable position of leadership as the "world's largest net exporter of electricity (World Nuclear Association, 2012) even supplying the 2012 London Olympics (Rose, 2012). Furthermore, Areva, "the world's biggest reactor builder," (Takemoto and Katz, 2008) and Electricité de France (EDF), the world's largest electricity utility (Hunkar, 2012), are French public companies.

The French relationship with nuclear energy commences with Marie Curie in Paris and her discovery of radioactive substances nearly a century ago. With regard to French culture, a "recasting of the symbols of French identity in technological form" (Hecht, 1998, p.89) began during the 1950s and 60s with the nuclear programme as a key driver of post-war reconstruction. Reactors were assimilated into the landscape variously as the "chateaux for the 20th century" (Hecht 1998, p.220) and "cathedrals" (p.223). Thus, as the industry moved from generation to generation, the reactor became a logical extension of national symbols such as Notre Dame, the Arc de Triomphe and the Eiffel Tower (Hecht, 1998, p.215). Charles de Gaulle vowed technological strength would lead the way to "grandeur" (Hecht, 1998, p.93; de Gaulle, 1960). Subsequently, nuclear energy was billed as a solution to the energy crisis. The advertising slogan "All electricity, all nuclear" was used by EDF to promote the reactor construction programme (Hecht, 1998, p.319). Political discourse throughout the 70s and 80 s continuously equated nuclear power with energy independence. The reliance on offshore uranium to support the industry is still quietly ignored (Granville, 2012), yet leadership in the nuclear sector implies France is the master of its own destiny.

In a number of countries including the United Kingdom, America and Middle East countries the nuclear power industry is known for secrecy. In Japan, even post Fukushima, "shady payments ... to local governments have continued since the reactor meltdowns at the Fukushima No. 1 nuclear power plant" (Ashahi Shimbun, 2012). In France, secrecy surrounding the nuclear industry is a legacy of its military beginnings and elite administration of technocrats forming a "closed intellectual circuit" (Baisnée, 2001, pp. 163-164). Historically, the French nuclear program is a centrally managed technological project and administrative matter (Hecht, 1998, p.11; Kitschelt, 1986, p.75; Garraud, 1979, p.450) free from public consultation. This state of affairs has had consistent support from governments on both the left and right with an acquiescent media (de Castries, 1971) reinforcing a pronuclear stance.

Given the 60-year political consensus promoting nuclear power, the economic force of the industry as an employer and the pervasiveness of nuclear energy as part of French culture, no surprise exists as to why a national debate about nuclear power remains elusive. Certainly, concessions to the opposition were made during the 1980s with the abandonment in 1981 of a reactor construction in Brittany and closure of the fast breeder reactor Superphoenix in 1998. In late 2005 to early 2006, a public debate under the auspices of the French National Commission for Public Debate (CNDP; Sugier, 2009) considered the matters of electricity lines, radioactive waste and the third generation EPR (European Pressurized Reactor), Flamanville3. Environmental groups withdrew from the debate claiming EDF refused to release documents evaluating risk. (Piquard, Le Monde, 2011). Wide-ranging environmental talks from 2007, known as the Grenelle de l'Environnement embraced objectives on renewable energy generation but did not challenge nuclear generated-electricity outright in terms of reducing the quotient (Crosemarie, 2012). 
A referendum on nuclear power has never been held in France. In neighbouring countries, public opinion polls have led to a full or partial withdrawal from nuclear energy production. Sweden held a referendum in 1980 with a reversal from anti-nuclear taking place nearly 30 years later in 2009. Post-Fukushima, Italy reinforced an anti-nuclear position and the German government decided to retreat entirely from nuclear power production.

What of France? The industry has been known for its closed "technocratic" administration and secrecy and there is a perceived lack of debate. However, following the stimulus of the nuclear power accident at Fukushima, could it be the French now entering into conversations and debates about the nuclear industry? Where are these conversations taking place?

Study of the civic online debate showed activity concentrated in newspaper forums. The research examined user-generated content (UGC) in these forums following a specific Greenpeace action aimed at highlighting reactor security. The story generated a certain amount of discussion in the space hosted by three main daily French newspaper sites. Most of the UGC however, reacted specifically to the Greenpeace event. This suggests the UGC is sensitive to the news agenda and the story carrying the interactive space. The long term implications are that the public debate may be curtailed by episodic spikes which follow the daily news agenda, such as the data examined here. The dialogue is therefore discontinuous; it exists at a specific moment and is agenda-dependent, nevertheless the forums create value by offering citizens a way of building opinion through interaction (Chambers, 1995, in Dahlberg, 2004).

\section{The Internet and public sphere}

The French have adopted the Internet en masse over the last decade. Against a background of declining print newspaper sales (one national daily, France Soir in circulation since 1944 has gone into bankruptcy; Moscow Times, 2012), France is now the 3rd largest online retail market in Europe (Gill, 2012) behind UK and Germany with over 50 million Internet users (Internetworldstats, 2011) or over 77\% of the French population and 23.5 million Facebook users (Internetworldstats, 2012) representing 37\% of the population. The proportion of households with internet access rose from $12 \%$ to $64 \%$ in the 10 years to 2010 (Gombault, 2011). Internet usage amongst households creates the opportunity for members of the audience to contribute to a public sphere, creating, broadcasting, appropriating and recirculating content (Jenkins, 2001) in this "hybrid" media ecology (Jenkins, 2006).

As part of the electronic media ecosystem, online newspaper forums provide a platform for people to create content and to communicate with one another about specific issues. Discussion takes place in the conceptual framework (Berdal, 2004) of the "public sphere" (Habermas, 1962, 1989). Used as a normative ideal, the public sphere is a "forum of public communication: a forum in which individual citizens come together as a public and confer freely about matters of general interest" (McKenna, 1995). Many scholars agree public deliberation contributes to a strong democracy (Barber, 1984; Bucy and Affe, 2010; Dahlberg, 2010). Conditions favouring deliberation include: equality of access to the debate, rational argument among participants, the recognition of differences, room to reach a consensus which may or may not lead to action and autonomy from state and corporate power (Fairclough, 2003, p. 80; Dahlberg, 2010, p. 7-10). Today, the way in which citizens generate content by using social media and circulating news and information online potentially helps maintain a vigorous public sphere thereby contributing to the democratic process. This is of particular interest in a country where the nuclear policy debate has been restrained for historic, economic and political reasons. 
Factors concerning access to online debate and participation in the dialogue mean this potential is unevenly realised, moreover, income, education, gender, age and race all influence who says what in digital forums. In addition, the offline and online worlds mirror one another as those active in civil society are also more likely to be so on the Internet (Albrecht, 2006; Schneider, 1996, 1997). The data examined in this paper therefore cannot be regarded as representative of the French people. It may nevertheless provide an indication of whether or not French participants in online newspaper forums are challenging nuclear policy.

In contrast to the traditional media environment of 'letters to the editor', talk-back or literary journals, the online media ecology provides real time space for public interaction deliberating on nuclear energy and disrupting top-down information flows associated with mass media and government information dissemination. According to Surman \& Wershler-Henry (2001, in Flensted, 2011) "the real difference between the Internet and all preceding media forms lies in its relationship to the public. Online, people aren't just the audience - they are also the content (p.42). The newspaper commentary space means people can use the news by circulating it and interacting with others over certain subjects. As hosts of that space, newspaper publishers may be inherently supporting civic society which may in turn create community, foster trust and loyalty to a particular site. According to Dailey et al (2008), some editors believe that if users are attracted by the possibility of participation that, in turn, increases the number of news consumers.

As a communications medium, the Internet accelerates connectivity by being cheap and boundary-free assisting groups or individuals to meet online and talk. The Internet provides the tools for making voices heard (Dahlberg, 2001; Papacharissi, 2010). The traditional forum of the public sphere encompassing the physical encounters in the public spaces of coffee houses and mass media come together in an emergent (Macnamara, 2010) digital form with the convergence of online newspapers, blogs, polls, message boards, Facebook, Twitter and YouTube "reinvigorating mainstream media and democratizing news processes" (Garden, 2010). Online spaces provide the opportunity for French Internet users to debate nuclear power and government commitment to it. The user interaction on the newspaper sites takes place at two levels: audience reception in "the processes of making sense, interpreting and using the output", and transmission, incorporating the conversations between two or many individuals (Dahlgren, 2005). Importantly, "to point to the interaction among citizens whether or not it is formalized as deliberation - is to take a step into the social contexts of everyday life" (Dahlgren 2005, p.149).

\section{Fukushima 1 nuclear power plant and French elections}

A rupture in everyday life around the globe concerning the nuclear energy issue occurred on March 11, 2011 when an earthquake and tidal wave engulfed the Japanese east coast and triggered a meltdown at the Fukushima Daiichi ("number one") nuclear plant. In France, the accident generated important online activity. Google searches (Figure 1 and Table 1) that took place shortly after the meltdown illustrate the level of interest. 


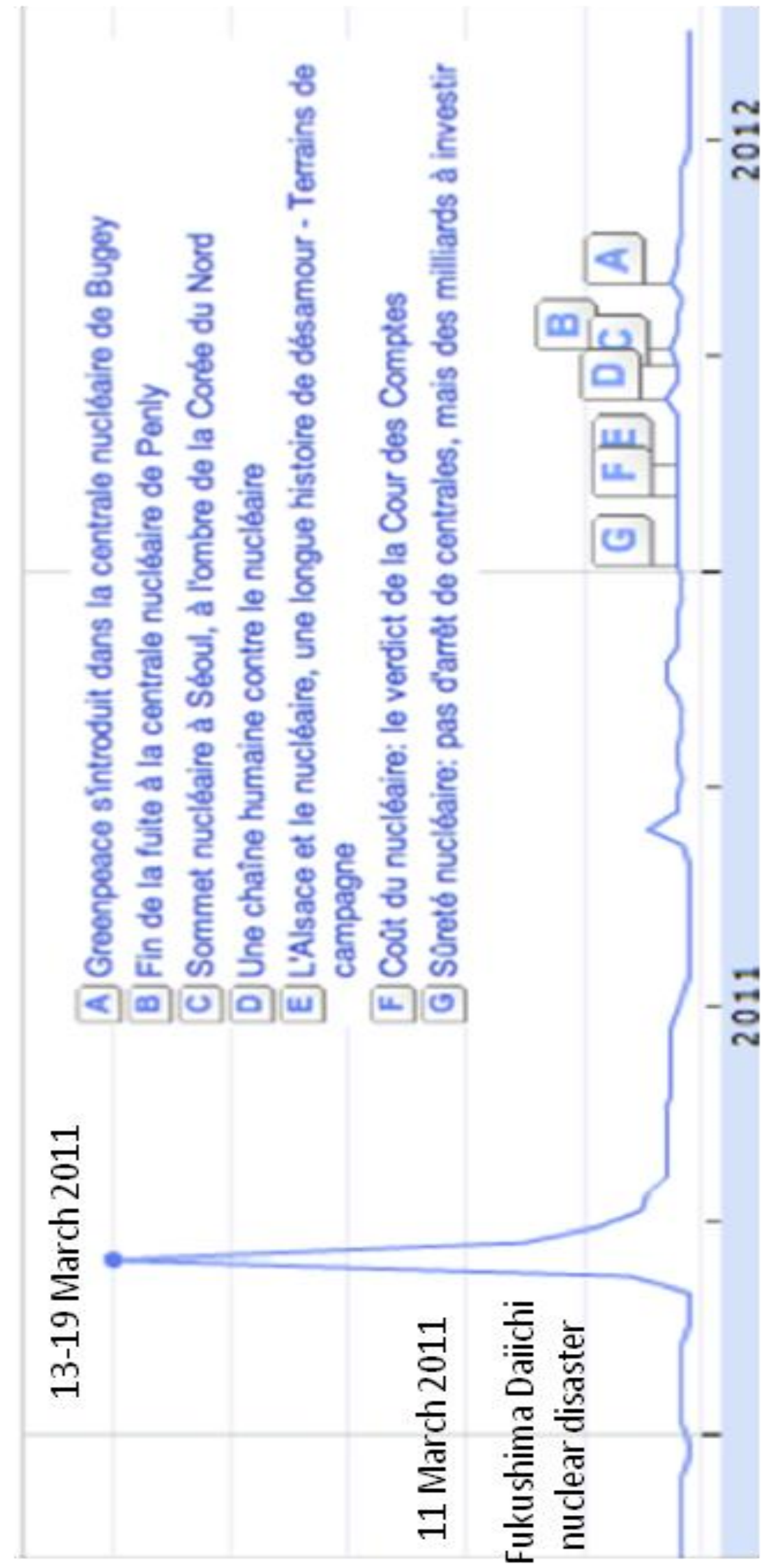

Figure 1. Google search interest in France (11/10 - 8/12): "nucléaire” (adapted from Google Insight for Search) 


\begin{tabular}{lll}
\hline 1 & Central nucléaire japon \\
2 & Fukushima \\
3 & Japon \\
4 & japon nucléaire \\
5 & nuage nucléaire \\
6 & nucléaire fukushima \\
\hline
\end{tabular}

Table 1. Google "nucléaire" centric search terms Growing $+5,000 \%$ in France (11/10 - 8/12) (adapted from Google Insights for Search)

The degree of concern in France is reflected in the Internet search spike (Figure 1). Street marches were also organised the Sunday (13 March) following the meltdown and environmental groups called for a referendum (Faut-il un referendum sur le nucléaire en France?, 2011, lepoint.fr). Fukushima impacted the presidential electoral calendar because nuclear safety and security suddenly became headline mainstream media issues. Eric Besson, the industry minister in the Sarkozy government, stated during a television debate "the presidential election is effectively a referendum" (Besson, 2011). The pressure was such that Socialist presidential candidate François Hollande promised to reduce dependence on nuclear energy to $50 \%$ by 2025 following a November 2011 deal with the green party Europe Ecology Les Verts (EELV). The 2012 French election campaign marked an unprecedented (Brouard et al, 2012) use of nuclear power as a political issue, stimulating debate on and offline.

\section{Online landscape and user content in French newspapers}

The online landscape under study comprises social media, online forums, regulator web sites, civil societies and newspapers (Figure 2). Mainstream media newspaper sites attracted the most user activity regarding nuclear energy discussions post-Fukishima. Dialogue in other online places is sparse in comparison with the newspaper social spaces. For example, a well presented and detailed blog published September 2011 (Fetet, 2011) concerning Fukushima Daiichi, attracted just two posts. Another blog about the comparative costs of electricity (Bernard, 2011) published November 2011 attracted 18 reactions via posts and 286 Facebook likes. Many academics use newsgroups as a source of content for analysis (Jenkins et al, 2012; Kelly et al, 2005; Papacharissi, 2004) yet a search of Google Groups using the terms énergie nucléaire on several occasions shows little or no spontaneous activity compared to the newspaper sites. Many websites hosted by civil society organisations (Friends of the Earth, Greenpeace and the Sortir du Nucléaire network) have interactive components for expression of opinion or seeking of information. The administrative Institut de Radioprotection et de Surété Nucléaire (IRSN), the watchdog Autorite de Surété Nucléaire (ASN) and the industrial organization Areva also provide online spaces for readers to leave comments. The Facebook Timeline for the Sortir de Nucléaire network representing 920 environmental groups and 57,000 individuals shows little public commentary and exchanges between two or more users but displays 5,999 "liking". The most popular age group is 25-44 year olds (Facebook, 2012). The observations pointed the research towards online mainstream media. Ultimately, the UGC on the web pages of the three main national daily newspapers, Le Figaro, Le Monde and Liberation was selected over other online content for analysis owing to the high degree of activity amongst readers. Not even the television and radio website spaces were as busy as the newspaper spaces. This indicates newspaper publishers are playing a key role in serving news to Internet users. Interactive features are 
now commonplace, but to what extent are they being used by people to debate? What might this say about how the French negotiate the issue of nuclear power online in a postFukushima world?

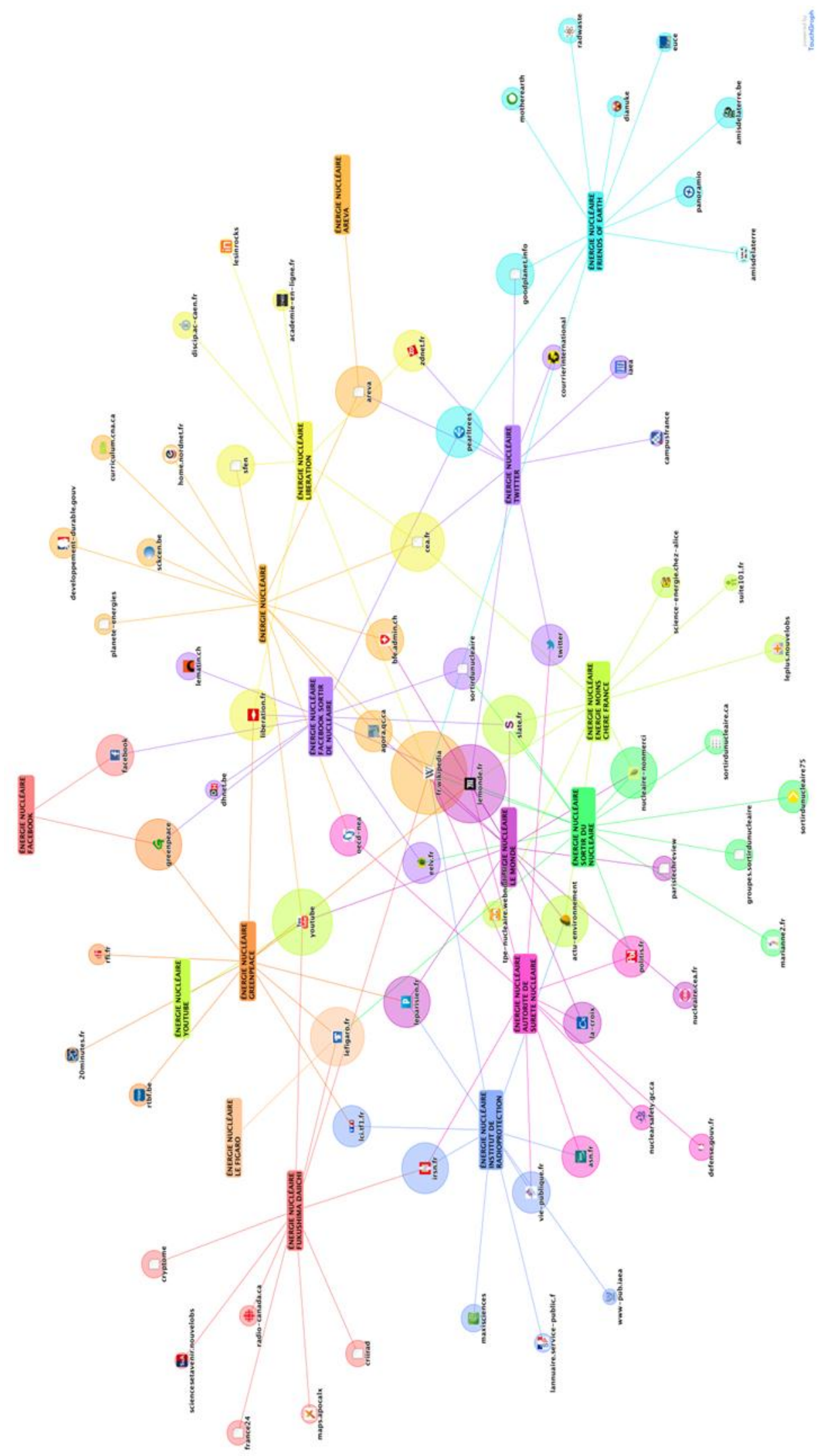

Figure 2. Online landscape of "energie nucléaire": social media, online forums, regulator web sites, civil societies and newspapers (Touchgraph 2012) 


\section{Methodology}

A computer-mediated discourse analysis informed the approach to understanding the nuclear debate online within the pages of the three national daily newspapers selected. These online papers embrace the spectrum of political persuasions: the left-wing Liberation, centre-left $\mathrm{Le}$ Monde and conservative Le Figaro. Susan Herring (2009) recommends best practices for Computer-Mediated Discourse Analysis (CMDA) as a sub-type of Content Analysis (CA). CA has traditionally involved adherence to research questions, samples and coding categories which refer back to traditional media studies. Herring argues for an expanded paradigm which includes different sample types applying to the Internet (time-based, event-based) and the possibility for coding categories to emerge from the data. In CMDA, as opposed to CA "various types of information 'contained' in new media documents include themes, features, links and exchanges, all of which can communicate meaning" $(2009$, p.11). Thus the act of recommending a news story via Facebook as a form of "clicktivism" (White, 2010) conveys the concerns and priorities of the reader as well as the meaning of the news text itself to a wider audience.

For French people, newspaper websites are increasingly a priority point of call for news and they offer the possibility to exchange opinion as well as engaging in symbolic approval of texts or "clicktivism". The three sites selected for the UGC study rank in the top 11 French sites overall in terms of visits at the time of the data uplift.

\begin{tabular}{llrlr}
\hline Newspaper & Visits December & Page views & Visits June 2012 & Page views \\
& 2011 & & & \\
\hline Lemonde.fr \#5 & $54,272,865$ & $181,608,699$ & $67,064,901$ & $238,563,424$ \\
Lefigaro.fr \#8 & $40,739,434$ & $201,947,942$ & $54,674,676$ & $257,842,061$ \\
Liberation.fr \#11 & $20,705,333$ & $65,835,759$ & $25,176,215$ & $81,955,914$ \\
\hline
\end{tabular}

Table 2. Source: French national press observatory OJD

A steady increase in news consumption can be seen over the seven months to the end of June, 2012 (see Table 2). While Le Monde leads the visits, Le Figaro consistently produces the largest number of page views. Between seven and nine percent of incoming traffic over the three news sites is via Facebook (Mentre, 2011).

These readership figures contribute a general impression of an active online population. Furthermore, this is reflected on the newspaper website indicating the comments a particular news story generates. Le Monde and Le Figaro pages indicate how many people have Facebook "liked" or "recommended" the news story. A closer examination of the sample from each site shows people reacting and circulating web news in different ways and reveals substantial differences in the UGC in terms of thread length.

Sampling (Table 3) took place on 5 December 2011 for a period of 2 days. The basic unit of analysis is the comment. The commencement of data collection is coincident with Greenpeace announcing a small number of members entering the Cruas nuclear plant 123 kilometres south of the third largest French city Lyon, and the Nogent-sur-Seine site, 95 kilometres southeast of Paris. This action drew attention to the issue of nuclear power plant security at the start of the presidential election campaign and just ahead of the release of a government-commissioned ASN (8 December, 2011) report on the security of nuclear power plants. 


\begin{tabular}{|c|c|c|c|}
\hline $\begin{array}{l}\text { Newspaper } \\
\text { Site }\end{array}$ & Liberation & Le Monde & Le Figaro \\
\hline Story $5 / 12$ & $\begin{array}{l}\text { "Greenpeace thwarts nuclear } \\
\text { plant security for } 14 \text { hours" }\end{array}$ & $\begin{array}{l}\text { "Greenpeace activists succeed in } \\
\text { entering two nuclear plants" }\end{array}$ & $\begin{array}{l}\text { "How nuclear plants are } \\
\text { protected" }\end{array}$ \\
\hline Link & $\begin{array}{l}\text { http://www.liberation.fr/soci } \\
\text { ete/01012375755- } \\
\text { greenpeace-opere-dans-une- } \\
\text { centrale-nucleaire }\end{array}$ & $\begin{array}{l}\text { http://www.lemonde.fr/planete/ar } \\
\text { ticle/2011/12/05/des-militants-de- } \\
\text { greenpeace-s-introduisent-dans- } \\
\text { la-centrale-de-nogent-sur- } \\
\text { seine_1613288_3244.html }\end{array}$ & $\begin{array}{l}\text { http://www.lefigaro.fr/act } \\
\text { ualite- } \\
\text { france/2011/12/05/01016- } \\
\text { 20111205ARTFIG00591- } \\
\text { comment-sont-protegees- } \\
\text { les-centrales- } \\
\text { nucleaires.php }\end{array}$ \\
\hline $\begin{array}{l}\text { How UGC } \\
\text { encouraged }\end{array}$ & $\begin{array}{l}\text { Top of page banner } \\
\text { invitation to register for } \\
\text { "MonLibé" space in order to } \\
\text { comment. } \\
\text { Comments flagged by } \\
\text { dialogue box with numbers } \\
\text { of comments made. } \\
\text { Facebook, Twitter and email } \\
\text { facilities above text of news } \\
\text { story }\end{array}$ & $\begin{array}{l}\text { A "réagir" or react button clicks } \\
\text { through to registration for access } \\
\text { to UGC page. Facebook, Twitter, } \\
\text { Google }+ \text {, Linked In, email } \\
\text { facilities above text of news story }\end{array}$ & $\begin{array}{l}\text { A "reactions" button } \\
\text { clicks through to UGC } \\
\text { and invites user to } \\
\text { register for commentary. } \\
\text { Facebook, Twitter and } \\
\text { Google + facilities above } \\
\text { text of news story }\end{array}$ \\
\hline $\begin{array}{l}\text { UGC tally } \\
\text { on page at } \\
\text { time of uplift }\end{array}$ & $\begin{array}{l}\text { Facebook button numbers } \\
\text { not published }\end{array}$ & Facebook "recommend" $=4980$ & $\begin{array}{l}\text { Facebook "like" }=107 \\
\text { Tweet }=42 \\
\text { Google }+=4\end{array}$ \\
\hline $\begin{array}{l}\text { Registration } \\
\text { for access }\end{array}$ & Required & $\begin{array}{l}\text { Required + minimum } 1 \text { euro per } \\
\text { month subscription fee } \\
\text { (reduced from } 15 \text { euros at time of } \\
\text { UGC uplift) }\end{array}$ & Required \\
\hline UGC visible & $\begin{array}{l}\text { Comments accessed via } \\
\text { click through }\end{array}$ & $\begin{array}{l}\text { Comments visible by scrolling } \\
\text { down page }\end{array}$ & $\begin{array}{l}\text { Comments visible by } \\
\text { scrolling down page }\end{array}$ \\
\hline $\begin{array}{l}\text { UGC posted } \\
5 / 12-7 / 12\end{array}$ & $\begin{array}{l}1282 \text { stated } \\
923 \text { in collected data }\end{array}$ & $\begin{array}{l}223 \text { stated } \\
223 \text { in collected data }\end{array}$ & $\begin{array}{l}179 \text { stated } \\
174 \text { in collected data }\end{array}$ \\
\hline
\end{tabular}

Table 3. Features of online articles to which people responded by posting commentary

\section{Discussion Density}

Liberation has both the highest number of posts (1282) and level of engagement between users. A breakdown of the UGC sample $(\mathrm{N}=668$ online comments for the three sites combined) reveals Liberation also has the greatest number of threads containing a minimum of three posts, which following Herring (2004) and Papacharissi (2004), indicates a greater density of discussion. The longest thread in the Liberation sample consists of 77 posts. The Liberation UGC exhibits signs of community. For example, users occasionally refer to themselves as "Libénauts" and occasionally recognize one another's online presence from past discussion.

Therefore the Liberation sample raises questions about the ways in which design may encourage participation and the cultivation of trust, which is valuable because it enhances the civic association critical "to the functioning of democracy" (Chadwick, 2007). 


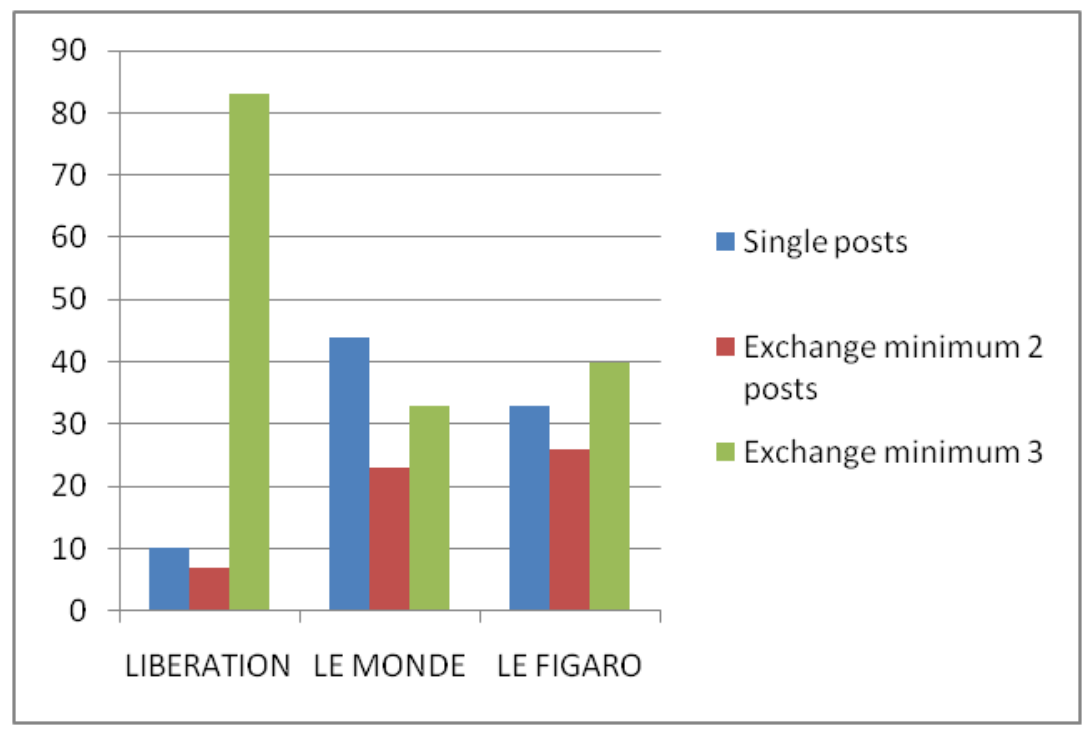

Figure 3. Percentage differences in thread commentary 05/12/2011

The Le Monde news story displays 223 posts. The publication requires (apart from blogs) a subscription fee prior to posting an online commentary however 4,978 people recommend the Le Monde Greenpeace story via Facebook, which they were able to do for free. This shows people care enough about the issue to pass the story on. Le Figaro's diagram of a nuclear reactor generated 129 comments. The UGC analysis shows the longest UGC threads in both the Le Monde and Le Figaro samples contain just five posts. These observations provide insights into how website architecture may affect the exercise of civic habits (Papacharissi, 2010) and how people take advantage of the interactive opportunities on the website news pages to set their own agendas.

\section{Research Design}

In order to understand more fully how the subject of nuclear power is treated by users in the selected sample, the data required repeated reading to "allow for the coding categories to emerge" following Herring (2009) and Kushin and Kitchener (2009) in their analysis of political discussion in Facebook groups. Drawing on this work and taking inspiration from the issue packages identified by Gamson and Modigliani (1989), nine coding categories were defined in order to analyze the UGC frames. Many people make comments about whether the NGO was right or wrong to conduct their action, whether they risked being shot, whether they ought to have been shot. A surprising number regard the Greenpeace action as "green terrorism" (LF\#77, Libé \#55). On the other hand, many champion the Greenpeace action for highlighting a perceived lack of security. For this reason, the first category was labelled "heroes and villains".

A second category was defined as "risk management" where talk concerns the possibility of an attack against a nuclear power plant and whether or not nuclear reactors would withstand an aircraft crash. These questions relate historically to the twin towers attack on 9/11 and publicity generated by NGOs pulling out of the previously government-organised debate in 2005 on the basis that EDF would not release classified information about reactor capacity to withstand such a crash (Piquard, 2011). One user posted a reply to another who had just said there was no need to panic: "Let's see now! The solution? Machine guns at the entry? An anti-air defence of 8 cannons? Even that's not foolproof. And that goes for any factory, except that in this case, if it explodes, it hurts!" (LM\#105). 
The "environment package" category covered talk on the cost of nuclear power, alternative energies, the treatment of radioactive waste, the situation in neighboring countries, the argument that nuclear power is a "clean" fuel compared to carbon-emitting coal or gas and references to Three Mile Island, Chernobyl and Fukushima. One user replied to another who said France is a mess behind a glossy exterior: "Who told you to stay? If you're not happy get out! Go and see if electricity is less expensive in Germany now that Angela Merkel has closed their reactors" (LF\#19).

The "public accountability" category concerned talk which put the blame for perceived security lapses squarely with EDF and the government for not doing enough to maintain safety standards:

\begin{abstract}
"It's the incompetence of those responsible for reactor security that we must sanction!..." (LF\#97).
\end{abstract}

"Sharing of Information" was included to cover posts where authors supplied links to other sites covering the nuclear issue or where the main purpose was to contribute a specific element to the discussion. In one example, the user stated that Greenpeace teams were at several sites and provided the link to Greenpeace's page where the organization was posting live coverage of its event (Libé\#229).

The "runaway" category directly follows Gamson and Modigliani's package which "suggests resignation and fatalism more than opposition" (1989, p.20). One such example stated: "the next Greenpeace operation [takes place] in four Chinese nuclear reactors. Marvellous." (Libé\#531).

An "other" category covers all talk relating to specific political positions, all statements off the subject, for example "you don't understand anything!" or "watch your spelling!" A final category covered insults, or "flaming".

The coding sheets contained one thread per page or pages according to the number of posts. Each post was identified by a number (to ensure privacy) plus the author's time of posting to facilitate cross-checking. Each post was given one value. The value equated to one of the nine categories developed and was allocated on the basis of the priority given by the post author; that is, when posts contained more than one category, the category allotted to the post was based on the bulk of the information contained in it.

\title{
Findings and discussion
}

A first main observation made from reading the data confirms Herring's (2009) view that the discussion forums represent a form of dialogue. Although it is text, the data is distinctly verbal in style. Nearly all the threads show dialogical tendencies as opposed to collective rants. A second general observation is that the issue of nuclear power cuts across party politics. A third observation is that there were no claims for a referendum in the data despite the fact that it had been such a major media issue earlier in the year.

In terms of process and measuring up to public sphere dialogue conditions (Fairclough, 2003; Dahlberg, 2010), authors within the threads disagree and differences are recognised but there is no striving toward consensus and little time for alliances to be formed although people did not hesitate to say "I agree with you". The UGC sample does not lead to action, however the 
ideas expressed have value because they show people thinking and talking about a subject that has for many gone unquestioned.

As mentioned, the large category of "heroes and villains" posts (see Table 4) meant many authors prioritised the Greenpeace action as good or bad without dwelling on the wider issues of nuclear power, risk management and environmental alternatives. However, taken together, the figures in these two latter categories show some people were venturing into this territory. Thus it can be deducted that moderate discussion was occurring outside of the conflict/responsibility (heroes and villains) media frame. The high percentage of "other" posts in Liberation's commentary may stem from the fact that the paper is left-wing and users more ready to criticize the Sarkozy executive than those of Le Monde and Le Figaro.

\begin{tabular}{|c|c|c|c|}
\hline Category & LIBERATION & $\begin{array}{l}L E \\
M O N D E\end{array}$ & $\begin{array}{l}L E \\
F I G A R O\end{array}$ \\
\hline Heroes and villains & $154(27 \%)$ & $33(45 \%)$ & $21(30 \%)$ \\
\hline Risk management & $60 \quad(10 \%)$ & $10(14 \%)$ & $14(20 \%)$ \\
\hline Environment package & $78 \quad(14 \%)$ & $7(10 \%)$ & $7 \quad(10 \%)$ \\
\hline Public accountability & $34 \quad(6 \%)$ & $9 \quad(12 \%)$ & $11(16 \%)$ \\
\hline Sharing of information & $(1 \%)$ & 0 & $4 \quad(6 \%)$ \\
\hline Runaway & $14 \quad(2 \%)$ & $2(3 \%)$ & $(1 \%)$ \\
\hline Insults & $16 \quad(3 \%)$ & $1(1 \%)$ & 0 \\
\hline Other & $162(28 \%)$ & $11(15 \%)$ & $12(17 \%)$ \\
\hline (suppressed) & $55 \quad(9 \%)$ & & \\
\hline Total & 580 & 73 & 70 \\
\hline
\end{tabular}

Table 4. Specific breakdown of the categories

An interesting feature that emerged in the coding was that when a participant posted a first or "seed" comment identified as either "risk management" or "environment package" the ensuing exchange tended to stick with the category or move between the two. For example, in a thread (\#22) of six in the Liberation group, one of the rare seed posts to take a direct stand against nuclear power begins by saying that security weaknesses and radioactive waste are two good reasons to quit nuclear power. The author continued the argument by saying that the alternative energy sector was creating jobs in Germany. The following posts take issue with the statement on the grounds that fossil-fuelled power plants employ more people in Germany than the alternative energy industry and that they contribute to greenhouse gases and thereby global warming. The discussion continued weighing up the costs of nuclear power and the investments required in alternative energy forms. The posts within the thread are all published in the space of an hour-and-a-half indicating engagement and interest in the subject.

Another feature of the data is the posts authored by people who claim to have specialist knowledge such as "I work in the nuclear industry, my dear..." (Libé \#5), "when I worked at a port in Algeria..." (Libé \#58) and "I work in the nuclear industry and these sites..." (LF\#3). The tone of the dialogue in the Liberation data is rough and tumble in comparison to the more cordial online atmosphere in Le Figaro and Le Monde forums demonstrated by the use of "messieurs...," ahead of a post or "bonne journée" at the end. This may be indicative of the demographics of the users attracted to each site. As mentioned earlier, Liberation users occasionally describe themselves as "libénautes"; a few recognise each other from past conversations and joke around ("you're being serious today" said one to another). This points 
to the issue of design and is deserving of further research in order to establish how website architecture affects the quality of interaction.

The UGC sample is influenced but not entirely governed by the media frames concentrating on the Greenpeace action and government and utility reactions. This is shown by the thread sequences talking about energy alternatives and by the posts where people are ready to talk about their personal experience of nuclear power. The findings show the space provided by the newspapers is being used by people as they get their news; they are participating and they are contributing. The act of entering into a rapid fire exchange of views implies reflective agency (Whipple, 2005). This type of discussion on nuclear power is a relatively new phenomenon in France, firstly because the emergent media ecology permits an asynchronous exchange which was limited a few years ago by the domination of a traditional media environment and secondly, because the subject post-Fukushima received so much coverage, alerting the public and forcing politicians themselves to debate the issue.

According to the IRSN 2012 report the number of French people judging nuclear reactors a risk $(55 \%)$ has never been as high. Paradoxically the same report finds the number of people citing energy independence and the low cost of electricity as arguments in favour of nuclear energy (67\%) also hits record high in this the 14th year of polling. According to another research report (Brouard et al, 2012), the publics' overall support for the nuclear industry is the highest it has been for 30 years. The authors' claim this is because of the exposure nuclear concerns received in the mainstream media during the presidential election campaign.

The right-wing executive particularly drew attention to employment issues and the need to support the sector. This may go some way to explaining why authors of UGC on December 5, 2011 did not mention a referendum on nuclear power and did not take outright issue with the industry.

The UGC does not feed into any prescribed process and is a far cry from contributing directly to an online consultation (Macnamara, $2010 \mathrm{~b}$ ). Scholars agree the internet consists of fragmented cyberspheres (Freelon, 2010; Papacharissi, 2002) of which the newspaper forums are an illustration, yet the forums under study can be categorised as "online political discussion" (Freelon, 2010). A chance to dialogue about nuclear power on news websites allowed people to address a scientific issue and by doing so, to claim it as their own, to digest it and to confront it, in a way that according to Benkler (1999) "accentuates the critical, reflective agency of the democratic public as creators and users" (Whipple, 2005, p.175). On the other hand, the provision of online commentary space is subject to the news agenda bringing an element of discontinuity to the public debate.

\section{Conclusion and implications for political communication}

The findings are somewhat intuitive in hindsight with important online communication taking place in the social spaces of the French newspapers. Very limited discussions or debate appear elsewhere online in social media. Furthermore, a limited degree of vigorous discussion takes place on the newspaper sites. The potential rationale as to the lack of debate taking place both within and outside of newspapers is twofold:

1. During the course of the nuclear stories emerging from the newspapers, no online media outlet created a formal platform to discuss the topic of nuclear energy online in entirety. No record exists of even an online town hall meeting being held in the 
context of the newspaper spaces. The UGC just appears to form part of the general comments as a matter of routine with no distinction placed on the content of topics.

2. Government itself is not participating directly in a significant manner. Should online instruments of democracy (e.g. online consultation, polls or debates) be made available to French citizens, with ability to co-author nuclear policy in consultation with government, the results might be different.

The research data shows people are using newspaper websites to exchange views on nuclear power to a limited extent. The collective conversation is dominated by the framing of the news stories. Some people used the opportunity to express a wider opinion on nuclear power and on occasion stimulated others to follow suit. Only a few posts $(<0.05 \%)$ take outright issue with nuclear power policies indicating a historical frame favouring the nuclear programme.

Dahlberg (2001) argues media corporates are not the most suitable sponsors for democratic talk as they are compromised by profit-making ambitions. The UGC spaces are hence private venues offering a platform for the demonstration of mediated action in the 'hybrid' environment (Jenkins, 2006) where people mix and recirculate information, creating meaning and setting agendas of their own. This is public action in that it is one-to-many communication, often executed anonymously from the privacy of the home, the office, or from a mobile device where geographical location is no longer a constraint to participation in a conversation.

The research demonstrates that in France, newspapers have a role to play in facilitating online dialogue and public trust to maintain. This may be in their interests, if, as Daily et al. (2008) report, some editors believe participation may increase news consumption.

Follow up research with the newspapers to understand why UGC is being assimilated among journalists and media organizations is an essential next step. The role of the UGC may be secondary in comparison with the newspaper website stories. The social media landscape mapping shows the UGC as dependent on the mainstream news agenda, that is people are not going to sites to discuss issues surrounding nuclear energy at great length outside mainstream media. The studied data reveals most people reacted to the news story as opposed to using it as a departure point for discussion. This is confirmed by Brouard et al. (2012) who see public opinion concerning nuclear energy in France as dependent on media frames. Therefore, although the Internet affords new civic habits, in France at least, it appears debate is still conservative and subject to episodic spikes rather than long term reflection by the public. There are nevertheless clear indications that the events at Fukushima triggered a degree of soul-searching on the nuclear issue.

The last word goes to a law student (December 7, 2011, Le Figaro.fr) who commented in one of the Le Figaro UGC spaces reminding all about the impact of Fukushima on the French:

Before Fukushima, I thought nuclear power was a very useful source of electricity and that if we were careful about it, the energy was without danger. But I wasn't informed at all. After Fukushima, I completely changed my opinion. What's more if you look at the map of France from the association Sortir du Nucleaire, you will see that the country is a nuclear grid. 


\section{References}

Asahi Shimbun (2012, August 20). Nuclear power industry's shady payments since Fukushima crisis. Asahi Shimbun. Retrieved from: http://ajw.asahi.com/article/0311disaster/fukushima/AJ201208200103

L'authorité de Surété Nucléaire (ASNILl) (December 8, 2011). Retrieved from www.asn.fr/index.php/.../ECS-Rapport-de-1-ASN-12-2011.pdf

Baisnée, O. (2001). Publiciser le risque nucléaire. La Polémique authour de la conduite de rejets en mer de l'usine de La Hague. Politix, Vol. 14, $\mathrm{N}^{\circ}$ 54, p.157-181.

Barber, B. (1984). Strong Democracy: Participatory politics for a new age. Berkeley: University of California Press.

Beaupuy, F. and Connan C. (2012, July 8). Areva Looks to China as France Rethinks Nuclear Power. Bloomberg. Retrieved from: http://www.bloomberg.com/news/2012-0707/areva-looks-to-china-as-france-rethinks-nuclear-power.html

Benkler, Y. (1999). From Customers to Users : Shifting the Depper Structures of Regulation Toward Sustainable Commons and User Access. Federal Communications Law Journal, 52, p.561-579.

Berdal, S. (2004). Public Deliberation on the Web: A Habermasian inquiry into online discourse. Department of Informatics, University of Oslo, Norway.

Bernard, C. ( 2011, November 30). Nucléaire, éolien... quelle est l'énergie la moins chère en France? Slate.fr. Retrieved from: http://www.slate.fr/story/46785/nucleaire-eolienenergie-moins-chere-france

Besson, E. (2011, April 11). Mots Croisés programme. France 2 TV. Retrieved from: http://infos-tele.fr/revoir-mots-croises-video-11-avril-2011/

S. Brouard, F. Gougou, I. Guinaudeau, S. Persico (2012) : Les Français, le nucléaire et la campagne présidentielle 2012. CNRS, France. Retrieved from: https://sites.google.com/a/iepg.fr/trielec/resultats-analyses/enquetes-preelectorales/vague-4---fevrier2012/lesfrancaislenucleaireetlacampagnepresidentielle2012

Bucy, E. \& Affe, R. (2010). The Contribution of Net News to Cyber Democracy : Civic affordances of major metropolitan newspaper sites. In: X. Li (ed) Internet Newspapers: The making of a mainstream media. New York: Routledge.

Bybee, C. (1997). Media, public opinion and governance : burning down the barn to roast the pig. Unit 56, of the MA in Mass Communications. Department of Media \& Communication, University of Leicester, United Kingdom.

Chadwick, A. (2007). E-democracy: Social Capital, the Public Sphere and Citizen Engagement. Unit 88 of the MA in Mass Communications. Department of Media \& Communication, University of Leicester, United Kingdom.

Chambers, S. (1995). Discourse \& Democratic Practices in White, S.K. (ed). The Cambridge Companion to Habermas, Cambridge University Press. Cambridge, UK.

Crosemarie, P. (2012). Bilan du Grenelle de l'Environnement: Un nouvel élan. Paris, France. Retrieved from: http://www.lecese.fr/sites/default/files/pdf/Avis/2012/2012_04_grenelle_environnemen t.pdf

Dahlberg, L. (2001). The Internet and Democratic Discourse: Exploring the Prospects of Online Deliberative Forums Extending the Public Sphere. Information, Communication \& Society, 4:4, p. 615-633.

Dahlberg, L. (2004).The Habermasian Public Sphere: A Specification of the Idealized Conditions of Democratic Communication. Studies in Social and Political Thought, 10, p. 2-18. 
Dahlgren, P. (2005). The Internet, Public Spheres, and Political Communication: Dispersion and Deliberation. Political Communication, 22:2, 147-162.

Daily, L, Demo, L \& Spillman, M. (2008).Newspaper political blogs generate little interaction. Newspaper Research Journal 4.

De Gaulle, C. (1960, June 14). Conférence de presse du Général de Gaulle. Institute National des Archives. Retrieved from: http://www.ina.fr/economie-et-societe/vieeconomique/video/CAF88026987/allocution-radiodiffusee-et-televisee-du-general-degaulle.fr.html

Emirbayer, M. and Mische, A. (1998). What is Agency? American Journal of Sociology, 103(4): p.962-1023.

Facebook (2012). Sortir.du.nucleaire feed. Retrieved from: www.facebook.com /sortirdunucleaire.org

Faut-il un referendum sur le nucléaire en France?, (2011, March 14). Lepoint.fr via www.lexisnexis.com

Fetet, P. (2011, September 4). Construction of the Fukushima Daiichi. Fukushima.overblog.fr. Retrieved from: http://fukushima.over-blog.fr/article-la-construction-de-lacentrale-nucleaire-de-fukushima-daiichi-83298407.html

Flensted, S (2011). Exploring the Connection Between Newspaper Blogs and Sense of Community. School of Communication, University of Houston, USA.

Freelon, D. (2010). Analyzing online political discussion using three models of democratic communication. New Media and Society, Vol. 12, N 7, p. 1172-1190.

Gamson, W. \& Modigliani, A. (1989). Media Discourse and Public Opinion on Nuclear Power: A constructionist approach. The American Journal of Sociology, Vol. 95, №1, p.1-37.

Garden, M. (2010, May). Newspaper Blogs: the Genuine Article or Poor Counterfeits? Media International Australia, Incorporating Culture \& Policy, Issue 135

Garraud, P. (1979). Politique électro-nucléaire et mobilization: la tentative de constitution d'un enjeu. Revue française de science politique, Vol. 29, № 3, p. 448-474.

Gill, M. (2012, January 4). French Online Retail Overview, 2012. Forrester.

Gombault, V. (2011). Deux ménages sur trios disposent d'internet chez eux. Institut National de la Statistique et des études économiques. Retrieved from :

http://www.insee.fr/fr/themes/document.asp?ref_id=ip1340

Granvaud, R. (2012). Areva en Afrique: Une face cachée du nucléaire francais. Marseille, France: Agone.

Habermas, J. (1989, 1962). The Structural Transformation of the Public Sphere. Cambridge, UK: Polity.

Hecht, G. (1998). The Radiance of France: nuclear power and national identity after World War 11. Cambridge, MA: The MIT Press.

Herring, S. (2004). Computer-mediated discourse analysis: An approach to researching online behaviour. In: S. Barab, R. Kling and J. Gray (editors). Designing for virtual communities in the service of learning, p.338-376. New York: Cambridge University Press,

Herring, S. (2010). Web content analysis: Expanding the paradigm. In: J. Hunsinger, M. Allen, \& L. Klastrup (Eds.), The International Handbook of Internet Research, p.233249. Berlin: Springer Verlag.

Hunkar, D (2009, November 23). The Top 10 Global Electric Utilities. Seeking Alpha. Retrieved from: http://seekingalpha.com/article/174823-the-top-10-global-electricutilnuclear

Internetworldstats (2012), Internet World Stats. Retrieved from: http://www.internetworldstats .com/ europa. htm\#fr. 
Internetworldstats (2011), Internet World Stats. Retrieved from: http://www.internetworldstats .com/ europa. htm\#fr.

IRSN Barométre 2012. La Perception des Risques et de La Securité par les Français.

Retrieved from:

http://www.irsn.fr/FR/IRSN/Publications/barometre/Documents/IRSN_barometre_201 2.pdf

Jenkins, A., Nikolaev, A., \& Porpora, D. (2012). Moral Reasoning and the Online Debate About Iraq. Political Communication, Vol 29, No1, p. 44-63. Retrieved from: http://dx.doi.org/10.1080/10584609.2011.616876

Jenkins, H. (2001). Convergence? I Diverge. Technology Review, December, 2010.

Jenkins, H. (2006). Convergence culture: Where old and new media collide. New York: New York University Press.

Kelly, J., Fisher, D. \& Smith, M. (2005). Debate, Division, and Diversity: Political Discourse Networks in Usenet Newsgroup. Paper prepared for the "Online Deliberation Conference 2005”, Stanford University, May 24, 2005. Retrieved from: http://www.coi.columbia.edu/pdf/kelly_fisher_smith_ddd.pdf

Kitschelt, H. (1986). Political Opportunity Structures and Political Protest: Anti-Nuclear Movements in Four Democracies. The British Journal of Political Science, $\mathrm{N}^{\circ}$ 16, p. 57-85.

Kushin, M. and Kitchener, K. (2009). Getting Political on Social Network Sites: Exploring online political discourse on Facebook. First Monday, Vol. 14, $\mathrm{N}^{\circ} 11$. Retrieved from: http://firstmonday.org/htbin/cgiwrap/bin/ojs/index.php/fm/article/viewArticle/2645/235 0

Law student UGC quote (2011) retrieved from: http://plus.lefigaro.fr/article/greenpeacesintroduit-dans-une-centrale-nucleaire-20111205-618441/commentaires

Macnamara, J. (2010). Emergent' media and public communication: Understanding the changing mediascape. Public Communication Review, Vol. 1 No. 2, p.3-17.

Macnamara, J(2010b). The Quadrivium of Online Public Consultation: Policy, Culture, Resources, Technology. Australian Journal of Political Science, Vol. 45 No. 2, p.227 $-244$

McKenna, J. (1995). Politics, Participation and the Public Sphere. Unit 10 of the MA in Mass Communications (by Distance Learning). Department of Media \& Communication, University of Leicester, United Kingdom.

Mentre, M. (2011, April 22). Le Classement des 60 Premiers Sites d'Informations Français. Retrieved from: http://owni.fr/2011/04/22/classement-des-sites-dinfo-francais/

Moscow Times (2012, July 25). French Paper Owned by Billionaire's Son Goes Bankrupt. The Moscow Times. Retrieved from:

http://www.themoscowtimes.com/news/article/french-paper-owned-by-billionaires-songoes-bankrupt/462563.html

Oursel, L. (2012, July 16). Les Sagas du Pouvoir programme. BFM Business. Available: http://www.bfmbusiness.com/catchups/Luc-Oursel

Papacharissi, Z. (2004). Democracy online: civility, politeness, and the democratic potential of online political discussion groups. New Media and Society, Vol. 6, p. 259-283.

Papacharissi, Z. (2010). A Private Sphere: Democracy in a digital age. Cambridge, UK: Polity Press.

Porritt,J. (2012, March 13). How the UK is handing control of its energy future to France. The Guardian. Retrieved from: http://www.guardian.co.uk/environment/2012/mar/13/uk-energy-future-france.

Piquard, A. (2011, March 19). Un débat sur les choix nucléaires avait déjà eu lieu en 2005. $w w w . l e m o n d e . f r$ accessed via Lexisnexis. 
Putnam, R.D. (1993). Making Democracy Work: Civic Traditions in Modern Italy. Princeton NJ: Princeton University Press.

Putnam, R.D. (1995). Bowling Alone: America's Declining Social Capital. Journal of Democracy 6 (1) p.65-78.

Putnam, R.D. (2000) Bowling Alone: The Collapse and Revival of American Community. New York: Simon and Schuster.

Rose, M. (2012, July 27). Olympics-More French power flowing to Britain in time for games. Reuters. Retrieved from: http://uk.reuters.com/article/2012/07/27/oly-power-franceidUKL6E8IREYW20120727

Sayare, S. (2012, February 2). Wishing Upon an Atom in a Tiny French. New York Times. Retrieved from: http://www.nytimes.com/2012/02/03/world/europe/wishing-upon-anatom-in-a-tiny-french-village.html?pagewanted=all

Schneider, S. (1996). A case study of abortion conversation on the Internet. Social Science Computer Review, 14 (4): 373-393.

Schneider, S. (1997). Expanding the public sphere through computer-mediated communication: political discussion about abortion in a Usenet newsgroup. $\mathrm{PhD}$ dissertation. MIT, Cambridge, MA.

Sugier, A. (2009). Pluralistic case-study:new build in France The treatment of confidentiality in the public debate French EPR Flamanville. In European Workshop on the Aarhus Convention - Luxembourg, 24-25 June. Retrieved from: http://www.anccli.fr

Surman, M., \& Wershler-Henry, D. (2001). Commonspace: Beyond Virtual

Community. London: Prentis Hall.

Touchgraph LLC (2008), version 1.05 Touchgraph Navigator, Touchgraph LLC, New York . Available: http://www.touchgraph.com/navigator

White, M. (2010, 12 August). Clicktivism is ruining leftist activism. Guardian. Retrieved from: http://www.guardian.co.uk/commentisfree/2010/aug/12/clicktivism-ruiningleftist-activism

Whipple, M. (2005). The Dewey-Lippmann Debate Today: Communication Distortions, Reflective Agency, and Participatory Democracy. Sociological Theory, 23:2, p.156178.

World Nuclear Association (2012). Nuclear Power in France, July. Retrieved from:http://www.world-nuclear.org/info/inf40.html

Wright, S. and Street, J. (2007). Democracy, deliberation and design: the case of online discussion forums. New Media and Society, Vol. 9, p. 849-869. 